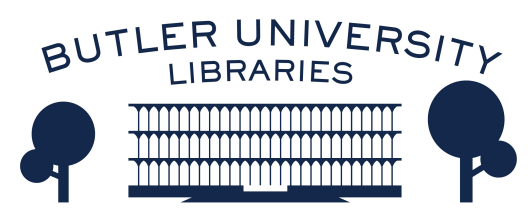

Journal of Hindu-Christian Studies

Volume 14

Article 11

January 2001

\title{
Viewpoint: Dialogue: A Call to Friendship
}

Kenneth Cracknell

Follow this and additional works at: https://digitalcommons.butler.edu/jhcs

Part of the Religion Commons

\section{Recommended Citation}

Cracknell, Kenneth (2001) "Viewpoint: Dialogue: A Call to Friendship," Journal of Hindu-Christian Studies: Vol. 14, Article 11.

Available at: https://doi.org/10.7825/2164-6279.1254

The Journal of Hindu-Christian Studies is a publication of the Society for Hindu-Christian Studies. The digital version is made available by Digital Commons @ Butler University. For questions about the Journal or the Society, please contact cbauman@butler.edu. For more information about Digital Commons @ Butler University, please contact digitalscholarship@butler.edu. 


\title{
VIEWPOINT
}

\section{Dialogue: A Call to Friendship}

\author{
Kenneth Cracknell \\ Bright Divinity School
}

IN the past twelve months we have lost three great figures from the active list of participants in Hindu-Christian dialogue: Wilfred Cantwell Smith (1926-2000), Ninian Smart (1927-2001), and Eric J. Sharpe (1933-2000). It is my keen sense of an ending of an era that leads to the reflections in this Viewpoint.

First I am struck by what a recent phenomenon interreligious dialogue is, as we know it. It really began in the lifetimes of these great people. To be sure there have always been people who have worked for Christian-Hindu understanding. In the early eighteenth century there was Bartholomew Ziegenbalg in Tranquebar (there's a fine new study by Briraj Singh showing him as a dialogue person). Eric Sharpe discussed Indian thinkers in such works as Faith Meets Faith and The Universal Gita, and I was able to remind us of some extraordinary Christians from a century or so ago in my Justice, Courtesy and Love. But the project we call "dialogue" owes much of its origin to the Jewish philosopher Martin Buber who shifted us all into an "I-Thou" frame of mind. In his 1929 work Zwiesprache (E. T. Between Man and Man), Buber wrote, prophetically enough, that a "time of religious conversations is beginning, not those so-called but fictitious conversations where none regarded and addressed his partner in reality, but genuine dialogues, speech from certainty to certainty, but also from one open-hearted person to another."

To have pushed the study of religion in this direction was the life-work of Wilfred
Cantwell Smith. His debt to Buber (which he often acknowledged) is apparent in his insistence on faith as an ubiquitous human quality and in his equally forceful rejection of the reification of religion. Our dialogue (or "colloquy" as Wilfred preferred to call it) begins when we get beyond the defense of ideologies and propositions; when we begin to ask, in Wilfred's phraseology, not what religion a person belongs to, but what religion belongs to that person.

But if the philosophical grounding of interreligious dialogue has been based upon a rediscovery of the human person as constituted by relationships (Buber, Macmurray and others), our commitment to work at interfaith dialogue has been made the more urgent by our world situation. We have all confronted the alternatives: nationalisms and colonialisms, narrow and frightened bigotries, cultural tribalisms and ethnocentricities, and, even in India, intensifying religious fanaticisms, and part of the world is exempt from these demonic forces. Students of religion and practitioners of dialogue know full well the importance of our task. But sometimes we too need to be reminded of the goal of both our study and our practice, particularly when we are tempted to get more interested in questions of theory and methodology. Fifty-four years ago, John Macmurray wrote that "all meaningful knowledge is in order to action, and all meaningful, action is in order to friendship."

Wilfred Smith's life-long search for such meaningful knowledge was born out of 
the despair he felt as he contemplated the partition of India amid the ruins of his beloved Lahore in 1948. Throughout his subsequent career he insisted that we must move from "we" talking about "them" to "we" talking about "us." We humans have to talk together of what religiously and spiritually has happened to all of us in the long processes of our differing histories. Such discourse he described as "world theology." Similarly, among the closing words of Ninian's last book is his insistence that all the differing parts of our global civilization must have a meaningful role in contributing to the whole. The supreme intellectual task is to find a frame-work within which often opposing "world-views" can live side by side. From his first experience of learning Chinese (as a military interpreter) and his pre-university time in Sri Lanka immediately after the Second World War, Ninian also knew himself to be about healing and reconciliation. But this towering intellectual never believed that such an understanding could "be imposed from above." It can only, he said, "well up from dialogue."(World Philosophies 1999, p. 372).

And it is only through this Buberian kind of dialogue that conflicts between world views can be dealt with. For in true dialogue a person speaks to a person "from certainty to certainty." Differences are never to be glossed over, or bulldozed away in the service of some other goal. Ninian believed joyfully that both the "construction and defense of world views" was a vital part of this activity. But in the dialogical process we grow and change. Here is Ninian's remarkable testimony in his and Steven
Konstantine's Christian Systematic Theology in a World Context. He wrote of his theological work that it was a darsana, and that, therefore, it was more than the presentation of an intellectual construction. IN a memorable sentence Ninian affirmed: "It is putting forward of a Tao, a form of bhakti and jnana...a life clothed in the sacramental $l i$, a stimulus to dhyana and karuna, an invitation to eschew shirk, and to be called by the power of the avatara." We must be grateful for such a modelling of the true way to present profound convictions in a multi-religious world.

In the Society for Hindu-Christian Studies we have made remarkable progress in making friends across the religious divides: the papers in this issue of the Journal represent but the tip of an iceberg of mutual learning, and many of us are deeply immersed in "world theology" in its HinduChristian form. But in moments of frustration, perhaps with each other, perhaps as we contemplate the sheer volume of the work that has to be done, perhaps arising from a sense of how inadequate our present level of discourse is, a historian's viewpoint may be important. We need to recognize that we are still in the early infancy of what will be the normal way of life for the scholars and sages of both our communities in the next decades. In their different styles Sharpe, Smith and Smart found ways through the impasse of mutual misunderstanding, suspicion, and cultural arrogance which mark the old relationship between our communities of faith. The excitement for each of us is to build upon this foundation. 